\title{
Desain Grafis untuk Meningkatkan Nilai Kaligrafi pada Santri dan Pengurus Pondok Pesantren Al-Hadi Kabupaten Demak
}

\author{
Abi Senoprabowo ${ }^{1 *}$, Ali Muqoddas ${ }^{2}$, Noor Hasyim ${ }^{3}$ \\ 1,2,3 Desain Komunikasi Visual, Universitas Dian Nuswantoro Semarang
}

A R T I C L E I N F O

Article history:

Received 20 August 2019

Received in revised form

10 September 2019

Accepted 30 October 2019

Available online 30

November 2019

Kata Kunci:

Desain Grafis, Kaligrafi,

Ponpes Al Hadi

Keywords:

Graphic Design

Calligraphy, Al Hadi Islamic

Boarding School

\begin{abstract}
A B S T R A K
Program PKM ini memiliki tujuan : 1) peningkatan kemampuan kewirausahaan santri pondok pesantren Al-Hadi dan Sultan Fatah melalui potensi kemampuan membuat kaligrafi digital, 2) peningkatan kesejahteraan santri dan pesantren yang lebih baik melalui pemanfaatan sumber daya yang memiliki nilai ekonomi, 3) terbentuknya usaha ekonomi pesantren dan kelembagaan yang terstruktur melalui unit usaha pesantren, 4) peningkatan kemampuan santri dan pesantren untuk melakukan diversifikasi produk. Kegiatan ini menggunakan dua pendekatan yaitu pendekatan pelatihan dan pendampingan. Pendekatan pelatihan meliputi : 1) Pelatihan Kewirausahaan; 2) Pelatihan dasar-dasar desain grafis, 3) Pelatihan digitalisasi kaligrafi, 4) Pelatihan pemanfaatan media online untuk pemasaran. Sedangkan metode pendampingan meliputi :1) Pendampingan penguatan sumber daya manusia melalui peningkatan pemasaran, manajemen, dan motivasi berwirausaha; 2) Pendampingan pembentukan kelembagaan Unit Usaha Pesantren; 3) Pendampingan ke akses permodalan. Diharapkan hasil dari kegiatan PKM ini adalah terwujudnya unit usaha pesantren dalam bidang kaligrafi, semakin meningkatnya jiwa wirausaha dan manajemen pada santri, serta peningkatan kemampuan pemasaran melalui media online.
\end{abstract}

A B S T R A C T

The PKM program aims at: 1) enhancing the entrepreneurial skills of Al-Hadi and Sultan Fatah Islamic boarding schools through the potential of making digital calligraphy, 2) improving the welfare of students and boarding schools through the use of resources that have economic value, 3) the establishment of businesses pesantren economy and institutional structure through pesantren business units, 4) increasing the ability of santri and pesantren to diversify products. This activity uses two approaches, namely the training and mentoring approach. Training approaches include: 1) Entrepreneurship Training; 2) Training in the basics of graphic design, 3) Training in digitizing calligraphy, 4) Training in the use of online media for marketing. Whereas the mentoring method includes: 1) Assistance in strengthening human resources through increased marketing, management, and entrepreneurial motivation; 2) Assistance in the formation of pesantren business units; 3) Assistance to access to capital. It is expected that the results of the PKM activities will be the realization of the pesantren business unit in the field of calligraphy, the increasing spirit of entrepreneurship and management of students, and the improvement of marketing capabilities through online media. diversification from herbal waste in the form of spices soap and liquid organic fertilizer, and online marketing of herbal products and processed from herbal waste. This activity can increase the income of the Wonolopo Village community and create 2 new "UMKM", namely "UMKM Sabun Rempah" and "UMKM Pupuk Organik Cair" made from herbal waste.

\footnotetext{
* Corresponding author.

E-mail addresses: abiSenoprabowo23@gmail.com (Abi Senoprabowo)
} 


\section{Pendahuluan}

Pesantren merupakan lembaga pendidikan informal berbasis agama Islam. Berasal dari kata santri, pesantren dapat diartikan sebagai tempat bagi para santri untuk menuntut ilmu (Muhakamurrohman, 2014). Beberapa hal yang orang-orang awam kenal tentang pesantren adalah hal-hal yang berhubungan dengan kyai, santri, masjid, pondok, kitab, dan lain-lain. Pesantren mengajarkan kepada para santri tentang wawasan intelektual serta kemandirian, disamping ilmu agama sebagai ilmu utama yang diajarkan (Zuhriy, 2011). Pesantren dipimpin oleh seorang tokoh sentral yang disebut Kyai. Seorang Kyai menjadi tokoh sentral dari semua kegiatan di pesantren. Dalam kesehariannya santri dididik dengan sangat ketat untuk menanamkan karakter disiplin, sabar, penyayang, dalam diri para santri. Para Kyai mendidik santri dengan penuh perhatian untuk mencetak kader-kader yang tidak hanya mengerti tentang ilmu agama tetapi juga dapat menerapkannya dalam perilaku sehari-hari. Para santri dididik untuk taat dan patuh dengan Kyai sebagai wujud cinta dan penghormatan terhadap ilmu pengetahuan (Diniyati, Fauziyah, \& Achmad, 2010). Tidak hanya pada Kyai, para santri juga harus menghormati teman seperjuangan, kitab-kitab dan yang paling penting adalah lingkungan sekitar. Hal ini menjadikan pesantren sebagai lembaga yang efektif untuk membentuk dan menyebarkan karakter bangsa yang sesuai dengan dasar Negara Indonesia yaitu Pancasila ke masyarakat sekitar. Walaupun lembaga informal, kiprah pesantren di dalam bidang kenegaraan sangat signifikan sebagai lembaga sosial yang terus merespons persoalan masyarakat di sekitarnya (Mujib, 2006).

Pondok pesantren yang melembaga di masyarakat, terutama di pedesaan merupakan salah satu lembaga pendidikan Islam tertua di Indonesia. Awal kehadiran Boarding School bersifat tradisional untuk mendalami ilmu-ilmu agama Islam sebagai pedoman hidup (tafaqquh fi al-din) dalam bermasyarakat (Mastuhu, 1994). Karena keunikannya itu, C. Geertz demikian juga Abdurrahman Wahid menyebutnya sebagai subkultur masyarakat Indonesia (khususnya Jawa). Pada zaman penjajahan, pesantren menjadi basis perjuangan kaum nasionalis-pribumi (Syafe'I, 2017).

Secara garis besar, Pesantren mengajarkan ilmu agama dan mengajarkan para santri untuk lebih mementingkan kepentingan akhirat dari pada kepentingan dunia. Namun para Kyai di pesantren juga menyampaikan pentingnya dunia untuk menunjang kepentingan akhirat. Para Kyai mengajarkan agar para santri harus dapat berjuang mencukupi kehidupan dunianya dalam menyebarkan ilmu agama. Para kyai menyampaikan untuk meneladani Nabi Muhammad yang menjadi pedagang yang sukses. Selain itu ada Nabi Zakaria yang berprofesi sebagai tukang kayu dan nabi Daud seorang tukang besi. K.H. Maimun Zubair, salah satu tokoh ulama besar yang ada di Indonesia, berpesan pada para santrinya agar ketika menjadi guru, dosen, atau kyai, para santri harus tetap membuat usaha sampingan agar tidak selalu mengaharap pemberian atau bayaran dari orang lain. Para kyai juga berpesan bahwa uang yang didapat dari usaha sendiri itu lebih berkah dibanding pemberian orang lain. Hal ini menandakan bahwa berwirausaha untuk para santri sangatlah dianjurkan. Santri yang memiliki pandangan setelah keluar dari pesantren berwirausaha, dapat memiliki harta lebih yang dapat dimanfaatkan untuk kepentingan masyarakat. Para santri juga memahami bahwa dalam agama islam, berwirausaha adalah sembilan dari sepuluh pintu rezeki yang ada.

Kaligrafi merupakan hal yang biasa ditemui di lingkungan pesantren. Kaligrafi adalah seni tulis tangan indah dan seni yang paling dihormati di antara berbagai seni rupa Islam (Ali, 2016) . Kaligrafi berasal dari bahasa latin kallos yang berarti indah dan graph yang berarti aksara. Jadi dalam kaligrafi, selain menyajikan tulisan atau huruf, terdapat juga aspek seni dan keindahan. Bahkan aspek seni dan keindahan menjadi aspek yang sangat penting. Di Indonesia, istilah kaligrafi sendiri identik dengan tulisan Arab yang dibentuk dengan bentuk yang indah (Purwanto, 2010). Kaligrafi yang mengandung nilai seni ini berpotensi memiliki nilai ekonomi yang tinggi bila dikemas dengan baik (Fitriani, 2011). Pesantren yang mengajarkan Agama Islam dengan kitab kuning, biasanya juga mengajarkan penulisan huruf Arab karena dibutuhkan untuk menulis makna dalam bahasa arab. Para santri walaupun tidak secara khusus mempelajari seni dalam berkaligrafi, mereka sebagian besar mampu membuat bentuk-bentuk tulisan Arab yang indah. Lingkungan pesantren yang sangat dekat dengan budaya Arab dan sifat manusia yang suka berkompetisi, menjadikan para santri berusaha untuk membuat tulisan Arab terbaik untuk menghias kamar masing-masing. Hal ini menjadikan stereotip di masyarakat bahwa santri pasti dapat menulis kaligrafi.

Pesantren dengan santri yang memiliki kemampuan kaligrafi merupakan potensi yang menarik untuk berwirausaha. Apalagi di era sekarang ini para santri tidak hanya dituntut untuk cerdas dan memahami ilmu agama, tetapi juga harus mampu berwirausaha untuk mendapatkan bekal dalam mencerdaskan dan membantu masyarakat memahami agama Islam (Lismarwan \& Nashori, 2010). Contoh pesantren yang para santrinya memiliki kemampuan kaligrafi adalah pondok pesantren Al-Hadi. Pondok pesantren Al-Hadi terletak di dusun Girikusuma desa Banyumeneng kec. Mranggen kab. Demak. Nuansa 
kaligrafi tulisan Arab sangat terlihat pada pesantren tersebut. Dinding-dinding pondok pesantren tersebut banyak dihiasi oleh kaligrafi yang dibuat oleh para santri sendiri. Pondok pesantren Al Hadi secara khusus mengajarkan ekstrakurikuler penulisan kaligrafi yang diadakan setiap hari selasa sore. Antusias para santri dalam mengikuti kelas tambahan tersebut cukup besar. Bahkan ada beberapa santri dari pondok pesantren Al Hadi yang menjadi wakil Kabupaten Demak untuk mengikuti ajang kompetisi penulisan kaligrafi antar pondok pesantren tingkat Jawa Tengah.

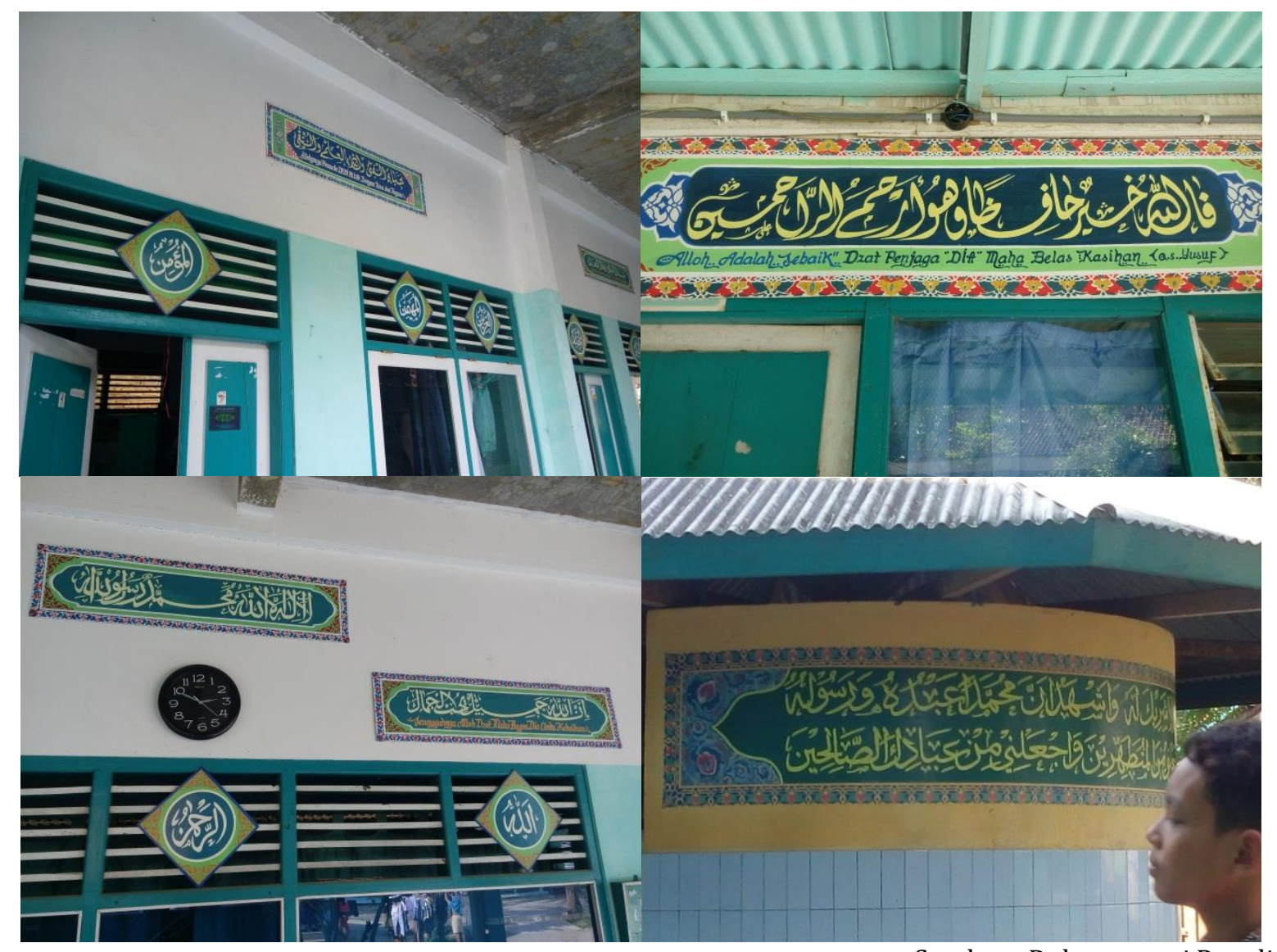

Sumber : Dokumentasi Penulis

Gambar 1 . Dinding pondok pesantren yang dihiasi oleh kaligrafi karya para santri

Pada era sekarang ini, masyarakat termasuk para santri memiliki kesempatan luas untuk mempelajari segala jenis pengetahuan. Perkembangan teknologi dan informasi menjadi pemicu santri belajar berbagai ilmu pengetahuan. Salah satu ilmu yang dapat dipelajari adalah desain grafis. Desain grafis yaitu membuat, merancang suatu produk dengan kombinasi bentuk, teks, warna, dan banyak hal lainnya yang menarik sehingga produk yang dihasilkan memiliki seni keindahan dan tingkat pemahaman yang mudah (Maharta, Nyeneng, \& Putu, 2015). Seni kaligrafi yang dibuat dalam bentuk digital memiliki beberapa keuntungan. Dengan digitalisasi kaligrafi dapat diperindah dengan bantuan perangkat lunak yang sekarang sudah banyak disediakan dan mudah untuk digunakan. Dengan digitalisasi kaligrafi memungkinkan untuk dijual secara masal serta mudah diaplikasikan dalam media apapun. Dengan digitalisasi dapat mengurangi resiko kerusakan pada seni kaligrafi tersebut. Dengan digitalisasi seni kaligrafi dapat dikenalkan dan dipasarkan secara global melaui media online (Zuliyati, 2015). Dengan solusi tersebut, maka pelatihan desain grafis dan digitalisasi kaligrafi diharapkan dapat menjadi ilmu baru yang dapat digunakan oleh satri dan pengurus dalam memanfaatkan kemampuan kaligrafi yang mereka miliki.

\section{Metode}

Metode pelaksanaan kegiatan ini adalah dengan melakukan pelatihan, implementasi, pendampingan, dan jejaringan. Program-program yang disepakati bersama antara Tim PKM dengan mitra untuk menyelesaikan permasalahan wilayah diuraikan pada tabel berikut ini, 
Tabel 1. Rencana program kemitraan masyarakat di Pondok Pesantren Al Hadi

\section{PROGRAM ASPEK DESAIN GRAFIS}

Pendampingan Diversivikasi Produk Kaligrafi

Pelatihan Dasar-Dasar Desain Grafis

Pelatihan Digitalisasi Kaligrafi

Pada kegiatan ini, mitra-mitra akan ikut berpartisipasi pada pelaksanaannya, antara lain :

1. Mitra menyiapkan peserta (Santri \& Pengurus Pondok) yang akan diberikan pelatihan

2. Mitra menyediakan tempat untuk pelaksanaan pelatihan.

3. Mitra menyediakan sebagian kelengkapan peralatan yang akan digunakan selama pelatihan berlangsung, misalnya : beberapa kabel rol, meja, listrik, peralatan sound system, dll.

4. Mitra menyiapkan peserta (Santri \& Pengurus Pondok) yang nantinya bertanggung jawab atas operasional media pemasaran online.

5. Mitra menyiapkan berbagai dokumen untuk kepentingan analisis data sebagai gambaran awal peserta pelatihan.

Untuk evaluasi pelaksanaan program dan keberlanjutan program dilakukan dengan beberapa cara yaitu,

1. Tim pendamping akan melakukan pendampingan selama 1 tahun agar usaha tersebut berjalan selama 1 tahun melalui pendampingan langsung maupun tidak langsung.

2. Tim pendamping menyediakan waktu untuk menjawab permasalahan apabila ditemui kendala dalam berjalannya usaha.

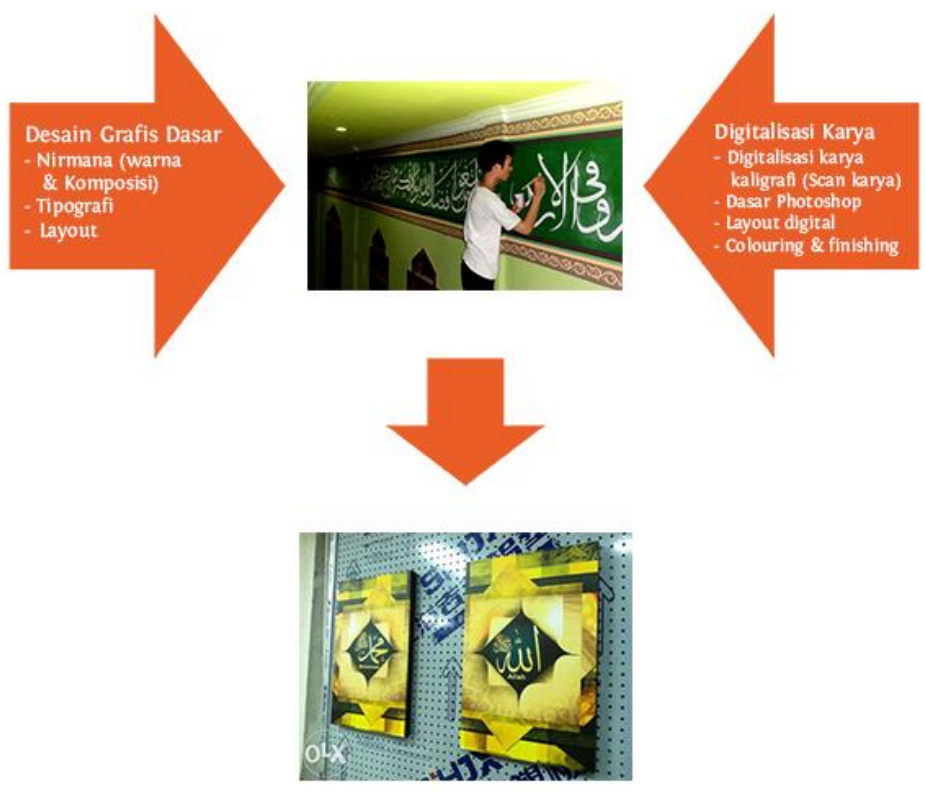

Gambar 2 Gambaran Transfer Iptek

\section{Hasil dan pembahasan}

Metode pelaksanaan kegiatan ini adalah dengan melakukan pelatihan, implementasi, pendampingan, dan jejaringan. Program-program yang disepakati bersama antara Tim PKM dengan mitra untuk menyelesaikan permasalahan wilayah diuraikan pada tabel berikut ini,

Realisasi program Pengabdian Kepada Masyarakat (PPM) ini dalam menjawab permasalahan di Pondok Pesantren Al Hadi dijabarkan dalam beberapa tahap diantaranya persiapan, pelaksanaan, khalayak sasaran, dan relevansi bagi perserta.

a. Persiapan Kegiatan Pengabdian Masyarakat

Persiapan pelaksanaan kegiatan pengabdian masyarakat diantaranya adalah sebagai berikut:

Melakukan survey atau peninjauan lokasi ke Pondok Pesantren Al Hadi untuk konfirmasi dan koordinasi dengan pengurus terkait ruang, materi yang dibutuhkan, jumlah peserta, koordinasi waktu dan lama pelaksanaan pengabdian, serta segala persiapan lain yang dibutuhkan. 


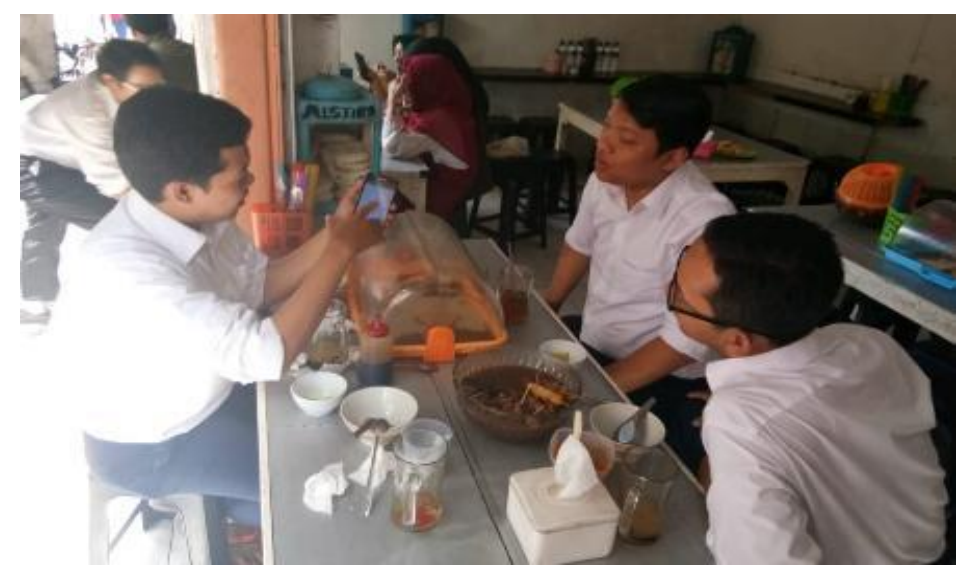

Gambar 3 Gambaran Transfer Iptek

Melakukan testing atau uji coba fungsionalitas peralatan pendukung pengabdian masyarakat seperti layar proyektor, sound system, komputer, laptop, dan printer yang ada di laboratorium komputer Madrasah Aliyah Al Hadi karena Pondok Pesantren Al Hadi tidak memiliki laboratorium komputer yang memadai.

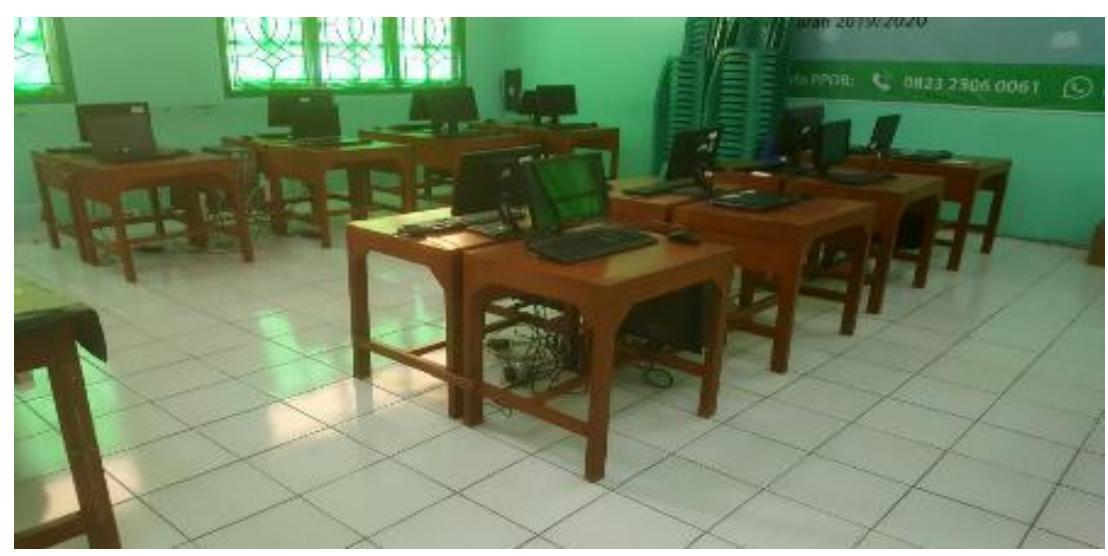

Gambar 4 Suasana Ruangan Laboratorium MA Al Hadi

1. Pembuatan materi teori untuk disampaikan kepada peserta. Adapun materi yang disampaikan berkaitan dengan kewirausahaan, desain grafis, dan pemasaran online. Sedangkan untuk praktek, materi yang dibuat berkaitan dengan digitalisasi kaligrafi dengan software corel draw dan potoshop, serta praktek pembuatan akun online shop.

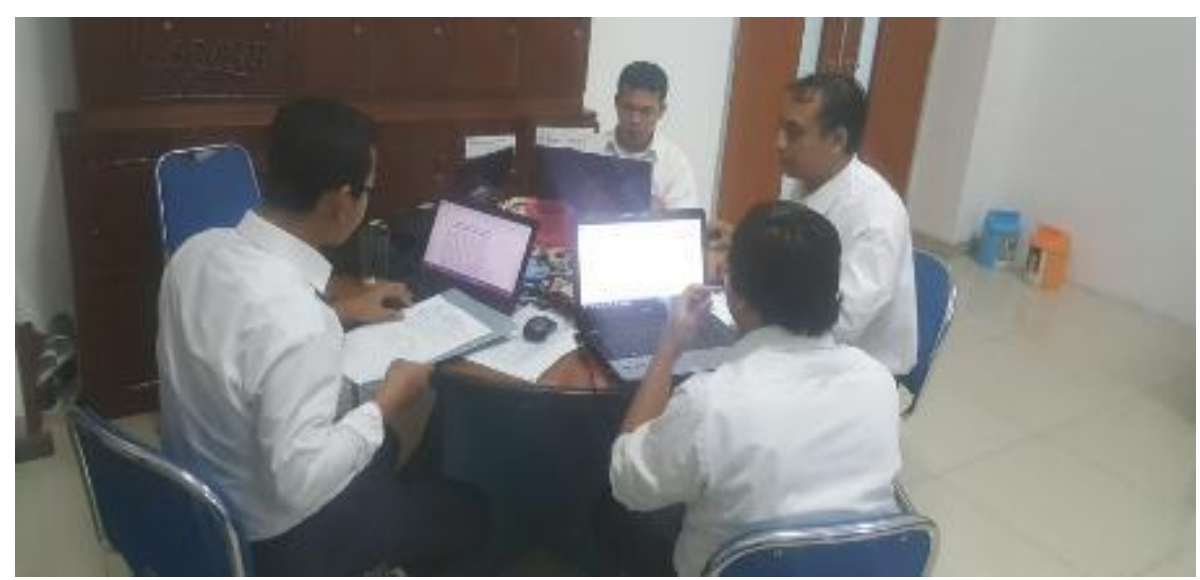

Gambar 5 Pembuatan Materi dan Soal Pre Test - Post Test 
2. Pembuatan soal pre test dan post test untuk dikerjakan oleh peserta. Pre test dan post test digunakan untuk mengukur tingkat ketersampaian materi yang disampaikan selama pelatihan.

3. Pembuatan dan cetak backdrop untuk pelaksanaan kegiatan.

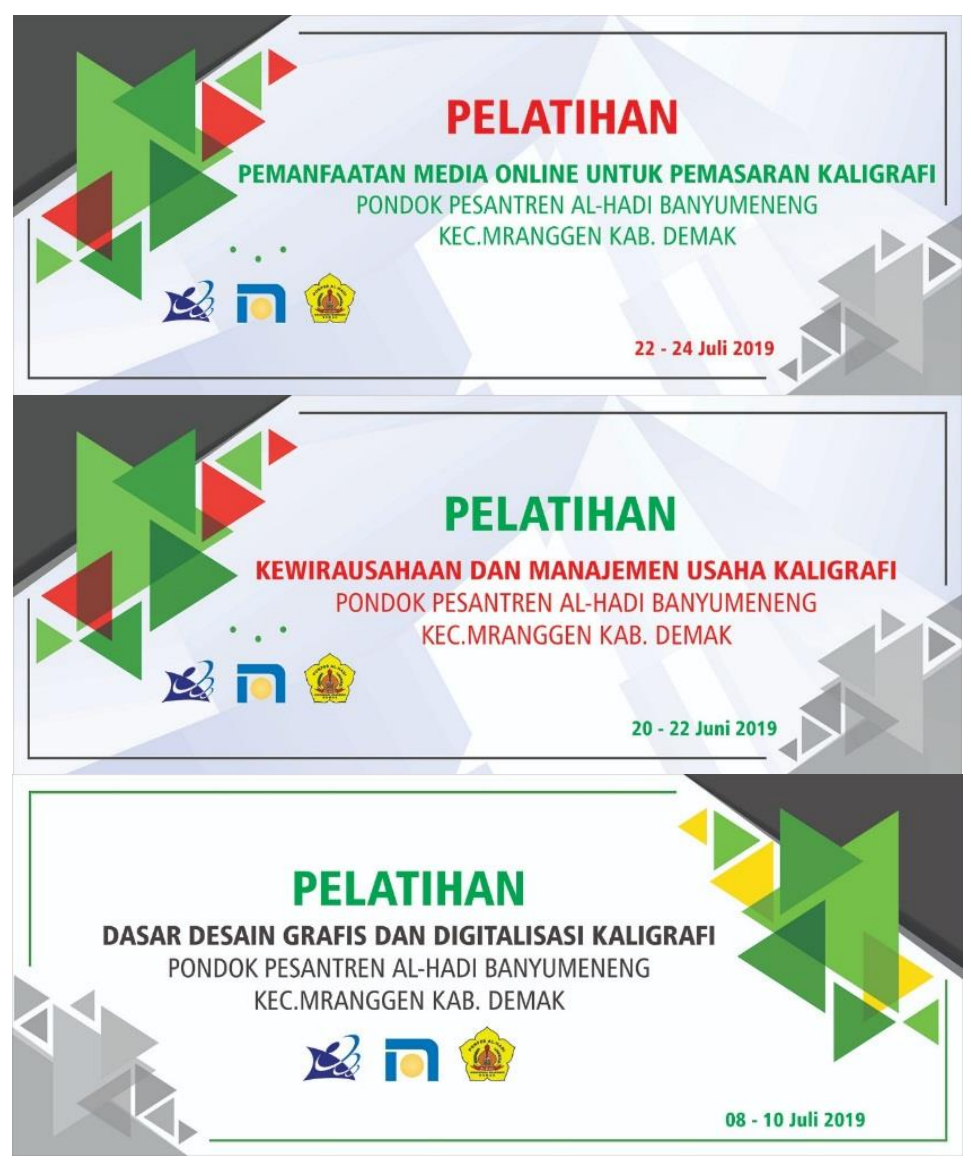

Gambar 6 Backdrop untuk kegiatan pelatihan

4. Melakukan persiapan alat perlengkapan yang akan digunakan dalam pelatihan, seperti pembelian flashdisk, cetak dan fotocopy materi untuk peserta, dsb.

Tabel 2. Jadwal Pelatihan desain grafis digitalisasi kaligrafi pada pondok pesantren Al Hadi

\begin{tabular}{|c|c|}
\hline Kegiatan & Pokok Bahasan dan Sub Pokok Bahasan \\
\hline $\begin{array}{l}\text { 1. Hari Pertama (8 } \\
\text { Juli 2019) }\end{array}$ & $\begin{array}{l}\text { a. Pemaparan materi tentang dasar desain grafis } \\
\text { - pengertian desain grafis } \\
\text { - unsur desain grafis } \\
\text { - kombinasi unsur desain grafis } \\
\text { - komposisi desain grafis } \\
\text { - layout (tata letak) } \\
\text { b. Praktek pembuatan Kaligrafi secara manual }\end{array}$ \\
\hline $\begin{array}{l}\text { 2. Hari Kedua } \\
\text { (9 Juli 2019) }\end{array}$ & $\begin{array}{l}\text { a. Praktek pemindahan Kaligrafi dari manual ke digital (Scanning) } \\
\text { b. Praktek mendesain Kaligrafi menggunakan Corel Draw (Tracing) }\end{array}$ \\
\hline $\begin{array}{l}\text { 3. Hari Ketiga (10 } \\
\text { Juli 2019) }\end{array}$ & $\begin{array}{l}\text { a. Praktek memindahkan desain dari Corel Draw ke Photoshop } \\
\text { b. Praktek Membuat tampilan mockup }\end{array}$ \\
\hline
\end{tabular}

Pelatihan ini dilakukan selama 3 hari yaitu pada hari kamis-sabtu tanggal 20-22 Juni 2019. Kegiatan ini dilaksanakan di laboratorium komputer Madrasah Aliyah Al Hadi. Kegiatan dilaksanakan dimulai dari pukul 08.00 sampai 14.00 WIB. Sesi pertama pada jam 08.00-11.30 dan sesi kedua pada jam 12.30-14.00. Waktu pelatihan hanya sampai jam 14.00 dikarenakan para santri dan pengurus harus melakukan kegiatan mengaji. Selain itu, mengingat ruang laboratorium terbatas hanya untuk 20 orang, 
maka peserta yang mengikuti kegiatan ini terbatas untuk 20 orang. Peserta yang mengikuti kegiatan ini terdiri dari pengurus dan santri terpilih. Kegiatan pengabdian masyarakat ini dilaksanankan dalam 3 (tiga) hari, yaitu

\section{Hari pertama (8 Juli 2019)}

Pada hari pertama, diawali dengan pembukaan yang diwakili oleh Ustadz Asmuni, M.Pd yang merupakan pengasuh Pondok Pesantren Al Hadi dan ketua kegiatan pengabdian ini yaitu Abi Senoprabowo, M.Ds. Pada sesi pertama, peserta diberikan pengetahuan tentang dasar desain grafis. Materi desain grafis diberikan dengan tujuan untuk memberikan pengetahuan tentang bagaimana mengelola titik, garis, bentuk, huruf, symbol, citra (image), ruang, tekstur, dan warna dengan baik. Materi yang diberikan berisi tentang pengertian desain grafis, unsur desain grafis, kombinasi unsur desain grafis, komposisi desain grafis, dan layout (tata letak). Materi ini disampaikan oleh Noor Hasyim, M.Ds. Pada sesi kedua, peserta diberikan kesempatan untuk merancang berbagai desain kaligrafi secara manual. Proses ini merupakan tahap awal peserta dalam membuat desain kaligrafi. Dari hasil tahap ini, peserta akan mendapatkan desain kaligrafi manual dengan warna hitam putih yang akan didigitalisasi pada hari berikutnya. Sesi ini dipandu oleh Ali Muqoddas, S.Sn, M.Kom.
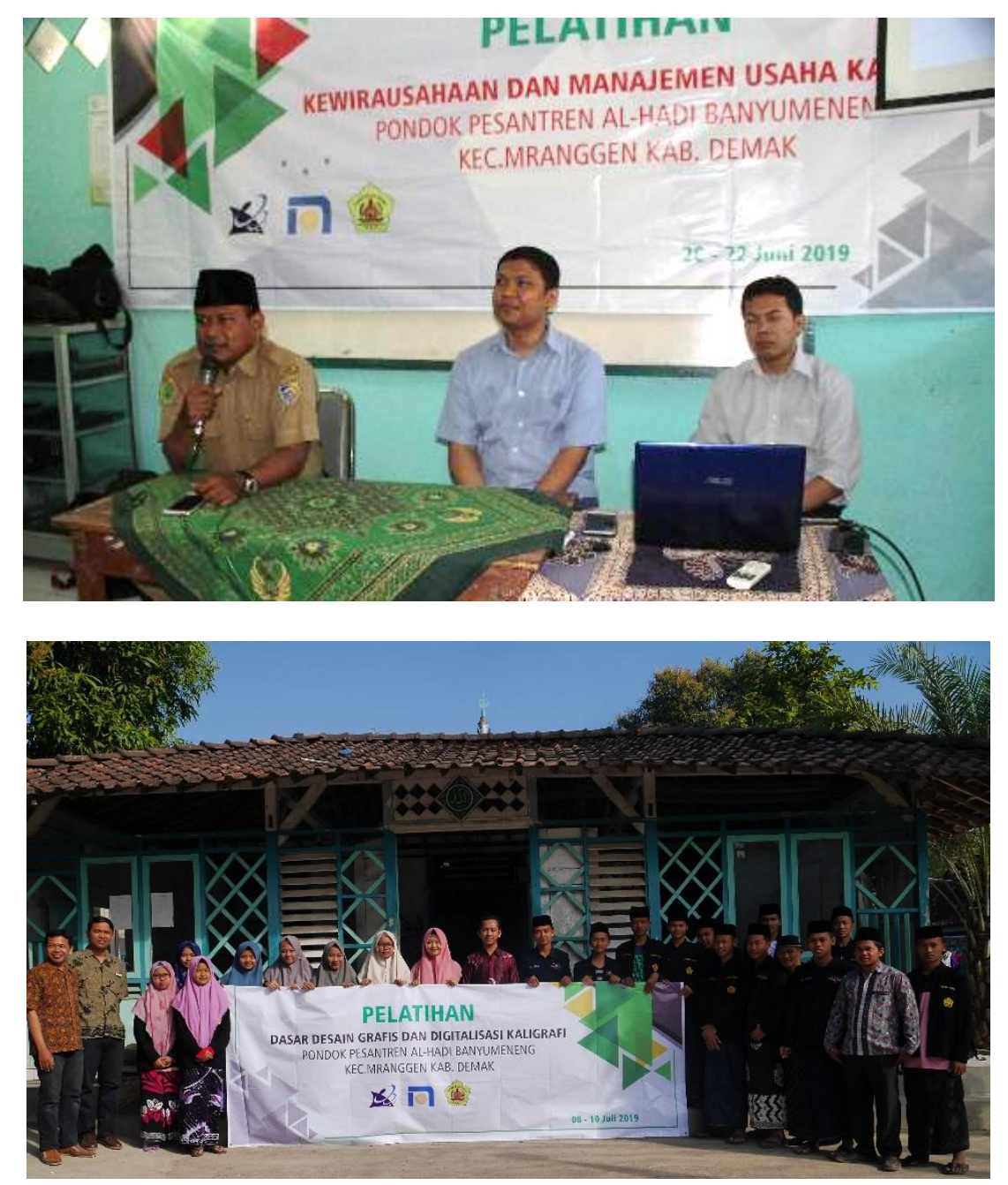

Gambar 7 Kegiatan dihari pertama

\section{Hari kedua (9 Juli 2019)}

Pada hari kedua, materi yang diberikan berfokus pada digitalisasi kaligrafi yang sudah mereka buat pada hari pertama. Sesi pertama, peserta diajak untuk menscan hasil kaligrafi mereka agar dapat didesain ulang menggunakan komputer. Peserta diharapkan dapat mengetahui cara menggunakan scanner agar hasil scan kaligrafi yang mereka hasilkan dapat didesain dikomputer dengan mudah dan hasilnya baik. Materi ini disampaikan oleh Abi Senoprabowo, M.Ds. Pada sesi kedua, peserta diajak praktek mendesain 
kaligrafi mereka dengan menggunakan software Corel Draw. Pada praktek ini, mahasiswa diajarkan memindahkan hasil scan menjadi bahan yang dapat diedit di Corel Draw atau dalam bahasa desain disebut proses Tracing. Setelah proses tracing, peserta diminta untuk memperbaiki desain yang sudah mereka buat agar menjadi lebih menarik. Pemateri pada sesi ini adalah Noor Hasyim, M.Ds.

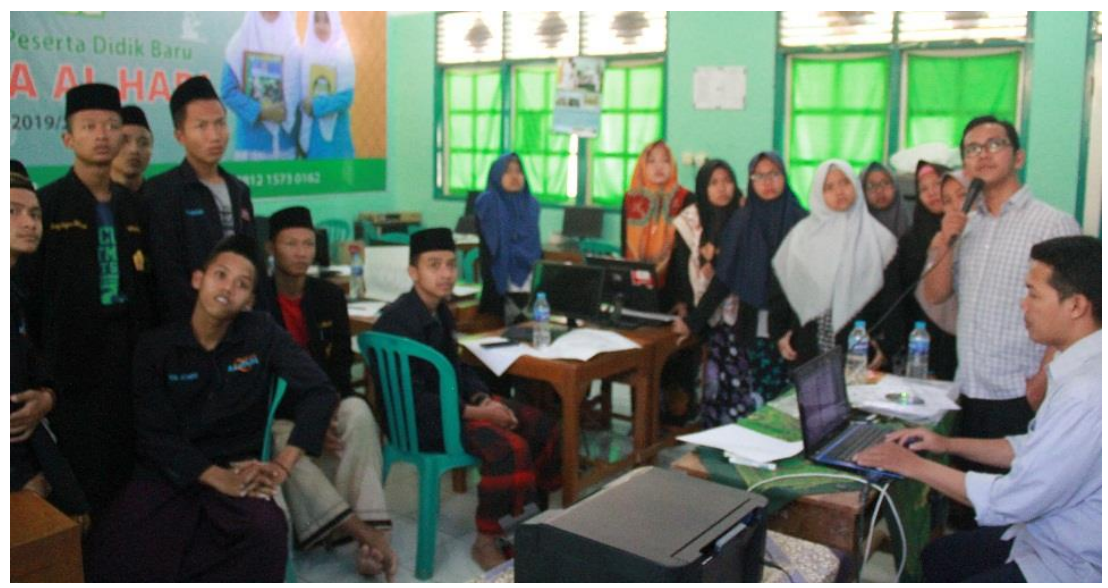

3. Hari ketiga (10 Juli 2019)

Gambar 8 Kegiatan dihari kedua

Peserta pada hari ini diberikan materi tentang bagaimana mempercantik tampilan dari desain mereka agar dapat menarik konsumen untuk membeli. Peserta akan diajarkan tentang membuat mockup desain pada sebuah kaos dengan menggunakan software Adobe Photoshop. Sesi pertama, peserta diajarkan tentang memindahkan desain yang sudah mereka buat dari Corel Draw ke Photoshop. Proses yang dilakukan adalah dengan mengekspor desain yang sudah mereka buat ke format PNG transparan. Materi ini disampaikan oleh Ali Muqoddas, S.Sn, M.Kom. Pada sesi kedua, peserta diminta untuk membuat tampilan mockup kaos yang berisi desain yang mereka sudah buat. Proses yang dilakukan adalah peserta diberikan beberapa template mockup kaos yang sudah dicarikan oleh pemateri. Dari template mockup kaos tersebut, peserta diajarkan tahapan memindahkan desain mereka ke dalam sebuah kaos. Pemateri pada sesi ini adalah Noor Hasyim, M.Ds.

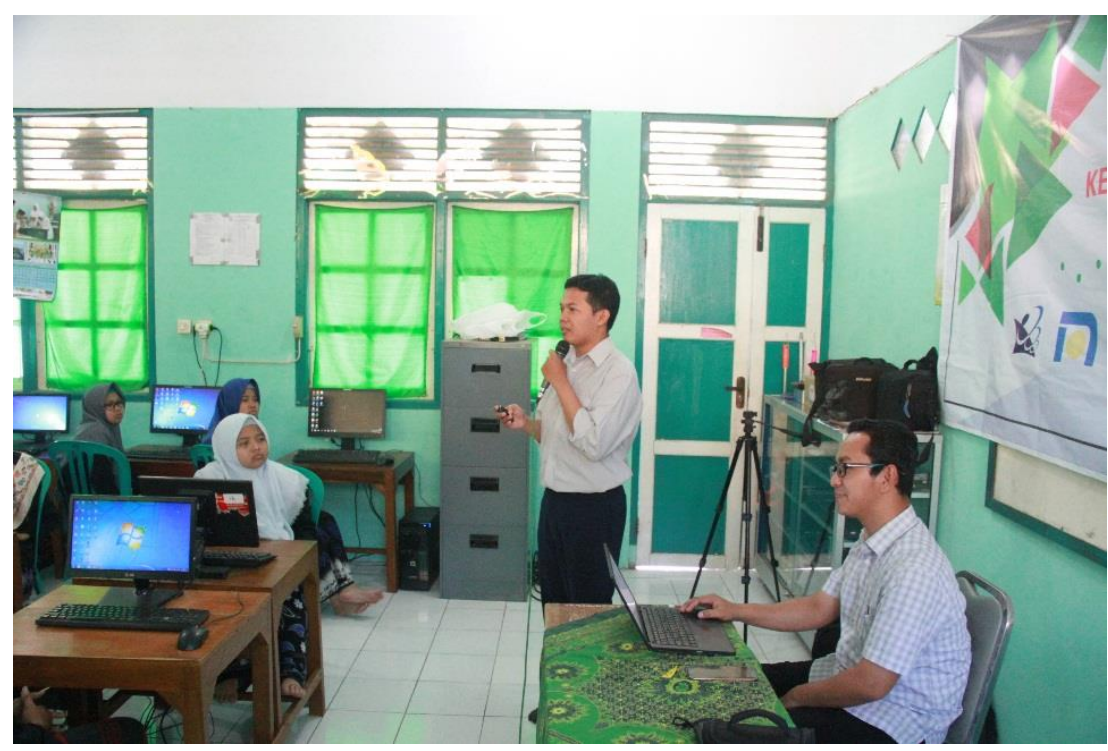

Gambar 9 Kegiatan dihari ketiga

4. Hasil kegiatan Pengabdian

Berdasarkan proses kegiatan selama pengabdian masyarakat berlangsung maka didapatkan beberapa hasil diantaranya adalah sebagai berikut :

Keluaran dari kegiatan ini yang utama adalah meningkatnya kemampuan santri dan pengurus pondok pesantren Al Hadi dalam melakukan Digitalisasi Kaligrafi. Selain itu peserta juga mampu 
menerapkan dasar desain grafis ke dalam karya kaligrafi mereka. Kemampuan mereka juga meningkat dalam hal penguasaan software Corel Draw dan Adobe Photoshop melalui simulasi dan praktek langsung yang telah dilakukan pada kegiatan pelatihan

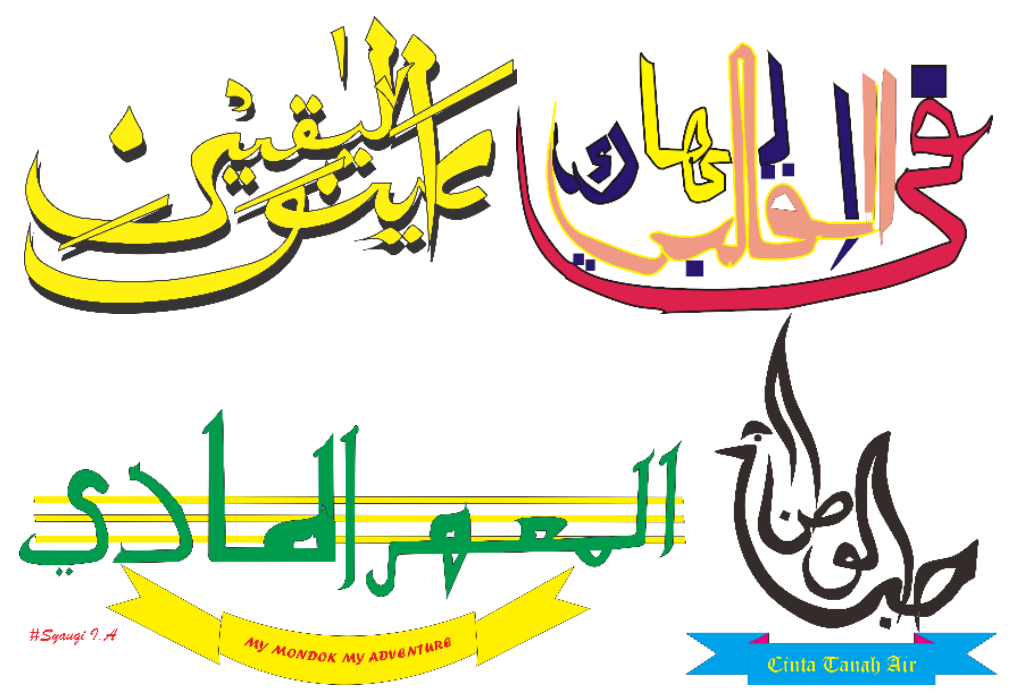

Gambar 10 Hasil desain kaligrafi menggunakan Corel Draw

5. Peningkatan bentuk produk yang dihasilkan oleh santri dan pengurus pondok pesantren $\mathrm{Al}$ Hadi yang terlihat pada bentuk kaligrafi yang sekarang dapat diaplikasikan pada kaos. Kaligrafi yang dihasilkan dari santri dan pengurus pondok pesantren Al Hadi biasanya hanya berupa hiasan dinding pada kamar atau Masjid.

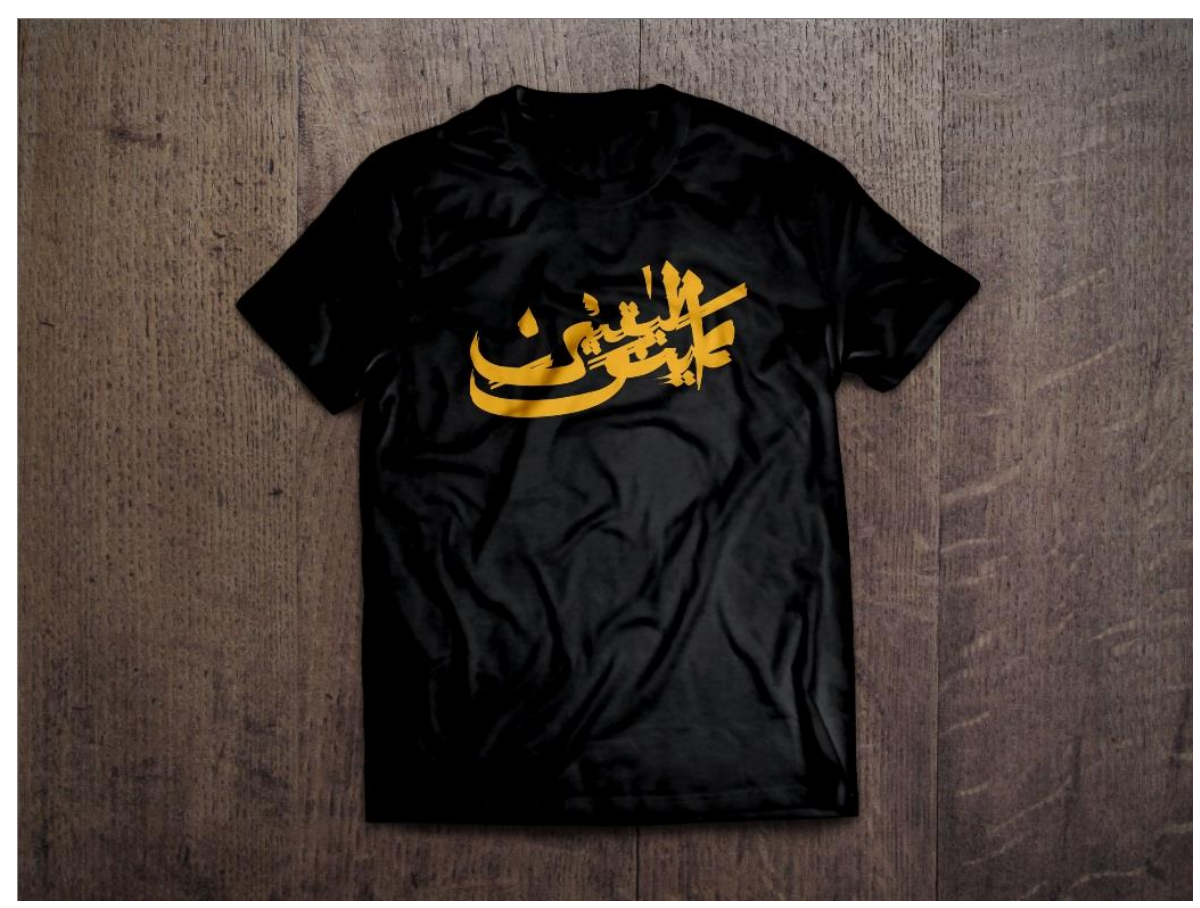

Gambar 11 Hasil desain kaligrafi menggunakan Corel Draw 


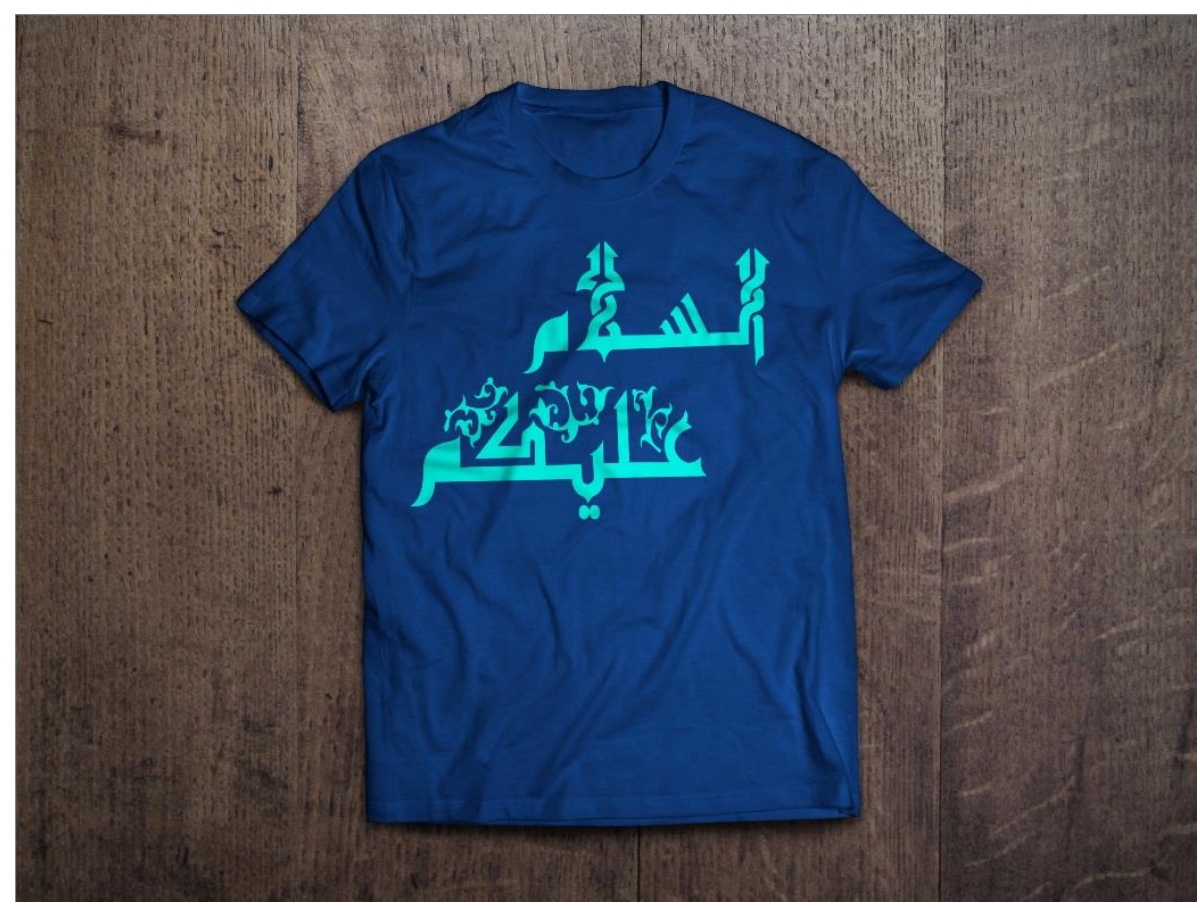

Gambar 12. Hasil desain kaligrafi menggunakan Corel Draw

6. Selain itu, terlihat juga semakin meningkatnya pengetahuan dan wawasan santri dan pengurus pondok pesantren Al Hadi mengenai pengertian desain grafis, unsur desain grafis, kombinasi unsur desain grafis, komposisi desain grafis, dan layout (tata letak).

\section{Simpulan dan saran}

Dari pelaksanaan kegiatan Pengabdian Kepada Masyarakat (PPM) untuk santri pondok pesantren Al Hadi melalui desain grafis dan pemasaran digital, dapat disimpulkan beberapa hal sebagai berikut: a) Peserta pelatihan merasa pengetahuan tentang dasar-dasar desain grafis mereka meningkat terbukti dari hasil post test yang meningkat, b) Peserta mampu mendigitalisasi karya kaligrafi menjadi lebih menarik, dan c) Peserta pelatihan mampu menggunakan software desain grafis untuk memperindah tampilan kaligrafi yang telah dibuat yaitu Corel Draw dan Adobe Photoshop.

Berdasarkan hasil kegiatan pengabdian masyarakat yang telah dilaksanakan memberikan banyak manfaat, maka saran untuk kegiatan selanjutnya adlah sebagai berikut: 1) Diharapkan kegiatan ini dapat menjadi program keberlanjutan, dengan pengembangan usaha pada produk lainnya seperti hiasan dinding, mug atau gelas, tas totebag, dan lain sebagainya, dan 2) Adanya monitoring dan aspek keberlanjutan program pasca pengabdian masyarakat ini sehingga diharapkan peserta yang mengikuti pelaksanaan kegiatan ini dapat tetap mempraktekan materi yang telah diberikan.

\section{Daftar Rujukan}

Ali, A. Z. (2016). Dakwah K.H. Moh. Faiz Abdul Razzaq (Studi Dakwah Melalui Seni Kaligrafi). Reflektika, $11(2), 15-31$.

Diniyati, D., Fauziyah, E., \& Achmad, B. (2010). Potensi dan Peran Pesantren sebagai Lembaga Pelaksana Kegiatan Rehabilitasi Hutan dan Lahan (RHL). Jurnal Penelitian Sosial Dan Ekonomi Kehutanan, 7(1), 41-54.

Fitriani, L. (2011). Seni Kaligrafi: Peran dan Kontribusinya Terhadap Peradaban Islam. El Harakah : Jurnal Budaya Islam, 13(1), 1-12.

Lismarwan, N. G., \& Nashori, H. F. (2010). Proses Kreatif Pelukis Kaligrafi Islam: Sebuah Penelitian Kualitatif. Proyeksi, 5(1), 1-16.

Maharta, I. W. A., Nyeneng, N., \& Putu, I. D. (2015). Pengembangan Komik Pembelajaran Fisika Berbasis 
Desain Grafis. Jurnal Pembelajaran Fisika, 3(5), 109-117.

Muhakamurrohman, A. (2014). Pesantren: Santri, Kiai, dan Tradisi. IBDA': Jurnal Kajian Islam Dan Budaya, 12(2), 109-118.

Mujib, A. (2006). Intelektualisme Pesantren: Potret Tokoh dan Cakrawala Pemikiran di Era Perkembangan Pesantren (III). Jakarta: Diva Pustaka.

Syafe'i, Imam. 2017. Pondok Pesantren: Lembaga Pendidikan Pembentukan Karakter . Jurnal Pendidikan Islam, Volume 8, No I 2017

Purwanto, Y. (2010). Seni Dalam Pandangan Alquran. Jurnal Sosioteknologi, 9(19), 782-796.

Zuhriy, M. S. (2011). Budaya Pesantren dan Pendidikan Karakter pada Pondok Pesantren Salaf. Walisongo: Jurnal Penelitian Sosial Keagamaan, 19(2), 287-310. 